\title{
Food Tourism: Opportunities for SMEs through Diaspora Marketing?
}

\begin{abstract}
Purpose: The aim of this paper is to investigate the impact of the diaspora effect on food tourism. Focussing on the nexus of diaspora marketing, entrepreneurship and food tourism, this paper seeks to explore opportunities for food and drink SMEs to engage in food tourism activities through diaspora marketing.

Design/methodology/approach: As an investigation of an under-researched concept, this research uses mixed methods to develop a deeper understanding of diaspora effects on food tourism. This includes an online survey of 169 food producers, with 37 follow-up interviews. Research was conducted with food producing SMEs in Wales and Brittany, two culturally and geographically similar places, where both the food and drink and tourism industries are significant parts of the local economy.
\end{abstract}

Findings: Two avenues for diaspora tourism are apparent, either through engaging with diaspora networks, such as expatriate networks located outside the country of origin, or through the reverse diaspora effect, of visitors experiencing products and then seeking to purchase them once returned to their countries. Both approaches depend on the ability for the food producer to sell their products to international buyers, as well as ensuring that international buyers had sufficient awareness of the products, which also links to a positive reputation for food.

Originality: The paper aims to take a novel approach to the impact of diasporas on food tourism by considering the entrepreneurial activity of businesses in developing opportunities for food tourism through diaspora marketing. Distinctions are made from existing research by studying diaspora tourism from the business perspective.

Keywords: Diaspora tourism, food tourism, diaspora entrepreneurship, internationalisation, regional food 


\section{Introduction}

Food tourism is an integral aspect of tourism, with an increasing body of literature exploring the various aspects of foods and how they connect with tourism. The breadth of food tourism is captured in the Hall and Sharples (2004, p. 10) definition, as "visitation to primary and secondary food producers, food festivals, restaurants and specific locations for which food tasting and/or experiencing the attributes of specialist food production region are the primary motivating factor for travel". The variety of activities encompassed within this definition underlines the role of both the product and place as significant elements of the food tourism offering, such as expressed in relation to beer (Bujdosó \& Szûcs, 2012). Motivations for beer tourism relating to the product include tastings, routes, or beer weekends; whereas place aspects include festivals, museums, or breweries.

A diverse body of literature exists on food tourism covering a range of aspects including tourism relating specifically to a product, such as wine (cf. Getz \& Brown, 2006; Gómez \& Molina, 2012) or beer (cf. Bujdosó \& Szûcs, 2012; Cabras et al., 2020); food visitor attractions (cf. Swarbrooke \& Page, 2012; Williams, 2013), events (cf. Cabras et al., 2020; Getz, 2008), and cultural identities through food tourism (cf. Everett \& Aitchison, 2008; Morgan \& Pritchard, 2005). These various aspects of food tourism are captured succinctly by Everett (2016). Additionally, there is increasing recognition within the literature of the importance of food as part of the tourism experience (Kunasegaran et al., 2019; Meneguel et al., 2019; Moscardo et al., 2015), as food represents a cultural experience relating to authenticity (Ellis et al., 2018), and a means to develop distinctions in a homogenised global setting. As such, food is a significant motivator for food tourism (Ellis et al., 2018; Kim et al., 2010; Robinson et al., 2018), and destinations are increasingly conscious of the value of local foods to tourism strategies (Du Rand \& Heath, 2006; Okumus et al., 2007), including experiences developed by food producers (Broadway, 2017).

While previous research on food tourism has considered these various aspects, particularly relating to the product, place, and visitor experience, this research focusses on the role of local food producers, and their role in promoting food tourism. As food and drink producers, tourism activities relating to the business are often secondary, such as visits to vineyards, as a means of supplementing income (Getz \& Brown, 2006), however, these activities can also provide value in developing a place identity (Everett, 2016).

Within tourism literature, there is a relatively small but growing body of research on diaspora tourism (e.g. Huang et al., 2018; Weaver et al., 2017). Generally, diasporas have become a point of increasing discussion in recent years, and research on diaspora networks is gaining traction within international business literature. In a global and interconnected modern society, over 244 million people now live outside of their country of birth (Huang et al., 2018), and countries are increasingly recognising the importance of diaspora networks in creating mutual benefit (Aikins et al., 2009). Diaspora networks represent strategies of uniting expatriates situation across the world, as well as foreign nationals with an affinity for the country, which could be considered a valuable resource for a country (Gamlen, 2005). Aikins et al. (2009) point to the ability of the diaspora network to foster strong international relationships which have the potential to enhance tourism, philanthropy and culture, as well 
as political and economic development. Countries such as India, Israel and Ireland have explored diaspora networks strategies in recent years. With 200,000 Indians based in Silicon Valley and 700 Silicon Valley companies wholly or part-owned by Indians (Aikins et al., 2009), the role of Indian expatriates cannot be underestimated, and their influence has been attributed to the success of the IT industry in Bangalore (Larner, 2007). For smaller countries, like Ireland, the role of the diaspora is potentially more significant (Kapur, 2001). With a population of only 4.4 million people, Ireland is a small country, however it has developed a far-reaching diaspora of an estimated 70 million people (Aikins et al., 2009).

This paper draws on the principles of diaspora marketing (Kumar \& Steenkamp, 2013; Elo et al., 2020) to explore the link between food tourism and the diaspora effect. With a limited focus on diaspora marketing in food tourism, the aim of this research is to evaluate entrepreneurial activity in developing food tourism opportunities through diaspora marketing. As a nexus of research on diaspora marketing, entrepreneurship and food tourism, a mixed methods research design is employed to provide a wealth of data from food and drink producers in Wales and Brittany to develop an understanding of their experiences of enhancing opportunities for diaspora marketing, as well as the benefits of food tourism in generating growth for the business. This aims to identify strategies for promoting food tourism, which could benefit the food business and local economy. Wales and Brittany were selected as the settings for this research, as both locations share similar cultural and geographical characteristics, based on predominantly rural areas, where food production is prominent. Comparisons could be drawn from these locations due to differences in the value of the food and drink industries in each location, as well as the numbers of tourists that visit each location, with Brittany eclipsing Wales on both of these factors.

Ultimately, the paper seeks to distinguish itself from previous research by exploring the intersection of food tourism, diaspora marketing and entrepreneurship to understand opportunities for food businesses to engage in food tourism. Contrary to previous research, which tends to view it from a tourist perspective, this paper looks at food businesses as the unit of analysis, aiming to understand how they could develop food tourism opportunities to support business growth. To achieve this, the research uses mixed methods as a means of taking a more holistic view of this concept, moving away from the dominance of purely qualitative research on diaspora tourism (Huang et al., 2018). The paper follows a traditional structure. The next section presents a review of literature relating to food tourism, food associations to place, and diaspora marketing, as well as theoretical underpinnings of network theory. Subsequently, the mixed methods research design is outlined and explained, before findings from the quantitative and qualitative research phases are documented and discussed, leading to conclusions and implications of the research for practice.

\section{Literature Review}

Given the aims of the paper outlined above, intersecting food tourism, diaspora tourism and entrepreneurship, this section reviews literature on food tourism, diaspora marketing in tourism and international business, underpinned by network theory. 
Food is an integral part of the tourism offering (Ellis et al., 2018; Kim et al., 2010), and destinations are increasingly placing more emphasis on suitable food tourism marketing strategies (Okumus et al., 2007). Food tourism is an established field of research that encompasses many different aspects; however the role of diasporas remains an issue that has gained little attention. Although some research on diaspora tourism exists (cf. Huang et al., 2016, 2018; Hughes \& Allen, 2010; Li \& Chan, 2017), particularly considering 'homecoming' travel of expatriates to their native country, the research on diaspora food tourism is more limited (Holak, 2014; Laing \& Frost, 2013), and largely relates to expatriates travelling to reconnect with food traditions of the native country (Huang et al., 2018). Foods have deeprooted connections with places, particularly through terroir, the unique characteristics, mostly associated with French wines, derived from the soil, climate, topography and local traditions (Charters et al., 2017). Aligning with resource-based view (RBV) theory (Barney, 1991; Teece, 2007), businesses can develop competitive advantage through unique resources. The unique characteristics of terroir foods represent valuable, rare, inimitable and non-substitutable attributes specific to place, distinguishing the foods of that place from similar foods elsewhere. Such food-territory associations are evident in foods with protected food names (such as PDO, PGI, or TSG) (Tregear et al., 2015), notable examples being Parma Ham, Champagne, or Colombian Coffee. Furthermore, this is evident in the cultural heritage of food products, such as the Cornish pasty, which has traditions as being eaten by miners in Cornwall (Bowen \& Bennett, 2020). These close associations of food to place can be marketed as a means to differentiate products (Testa, 2011), uniquely branding the product's 'senseof-place' (Hede \& Watne, 2013). This can also be exploited by food tourism destinations (Knollenberg et al., 2020), particularly since food is considered a cultural experience, to which authenticity is significant (Ellis et al., 2018).

The concept of diaspora marketing has emerged recently through the seminal paper by Kumar and Steenkamp (2013). They discuss the example of Dabur, an Indian manufacturer of herbal medicines, who originally targeted the Indian Diaspora in the United Arab Emirates before expanding to target Indian Diasporas in the UK and USA. Diaspora marketing is dependent on the expatriates having the mind-set to retain close links to their country of origin, as well as the universal appeal of the product, the size of the diaspora, the socioeconomic profile of the diaspora and its ability to help the brand grow globally. While literature on diaspora marketing focusses on connections with expatriates to their homelands (Huang et al., 2018), it largely overlooks the Reverse Diaspora Effect, in which tourists experience local products in a particular country and attempt to replicate the experience when they return home. Kumar and Steenkamp (2013) attribute the growing popularity worldwide of Thai food to this phenomenon. They also present the example of the Mexican beer brand, Corona, as discussed by Holt (2004), whose success is seen as the result of the emergence in the 1980s of Mexico as a destination for American students during their spring break, who then increasingly bought Corona upon their return home (Kumar \& Steenkamp, 2013).

As a process of developing international sales of a product, diaspora marketing effects can also be observed in internationalisation literature, particularly relating to SMEs, given their smaller size and limited resources. The importance of localised networks in triggering the first steps of the internationalisation process is highlighted through the case of fish exporters from 
the Azores islands (OECD, 2009), an autonomous group of Portuguese islands located in the middle of the Atlantic Ocean. Due to its isolated location, the fish exporters rely on links to emigrants in Canada and the United States (Camara \& Simeos, 2008), underlining the opportunities for national diasporas to facilitate internationalisation. Network theory within internationalisation literature points to a company developing its position in international market through establishing, building and sustaining foreign network relationships (Johanson \& Mattson, 1988). More recent literature on entrepreneurial ecosystems (cf. Isenberg, 2011; Ratten \& Rashid, 2020; Stam \& Spigel, 2016; van Schijndel, 2019) points to networks of several actors within an ecosystem that can facilitate entrepreneurial activity, including internationalisation. Furthermore, the theory aligns well with tourism, as it is described as a network-based industry, with networks at the heart of collaborative action across the industry (Mariani \& Baggio, 2020). The tourism industry is seen as a set of structured interdependencies and interactions between a range of actors (Czakon, 2014). Indeed, cooperative relationships among tourism actors are increasingly important in a globalised world (Kylänen \& Mariani, 2014; Mariani et al., 2014). Diaspora networks align with the principles of network theory in connecting companies to relevant actors in an international market that can help facilitate sales. The reverse diaspora principle represents international buyers discovering products in their country of origin, which therefore creates the link to an international market, as the visitor seeks to purchase the product once they have returned to their country (Kumar \& Steenkamp, 2013).

Figure 1 aims to conceptualise diaspora tourism based on the concepts discussed in this section. It outlines the relationships between the producer in the home market and the two avenues of diaspora tourism. Firstly, through expatriate contacts, who have a longing for familiar products from home, particularly food, and therefore seek to purchase products that they know. Secondly, the reverse diaspora effect is evident through tourists visiting a country and seeking to purchase products they experienced once they have returned home. Both approaches underline the importance of awareness for the product in order to motivate purchase from an international market. For expatriates this is born from their cultural value of the product, while for tourists it occurs through experiencing the product in-place. Both notions underline the importance of the place identity of the product, with food products possessing strong cultural associations to place through their terroir (Charters et al., 2017) and their unique place resources, as underpinned by resource-based view theory (Barney, 1991). The relations between the food producer and expatriates or visitors are underpinned by network theory, which underlines the social capital (Bourdieu \& Wacquant, 1992) between the different actors. Indeed, network theory in internationalisation points to the building of foreign relationships as an important aspect of selling internationally. Network theory in tourism research underlines that globalisation has led to increasing competition among companies in the tourism sector, but also increasing opportunities for cooperation, with cooperative relationships becoming increasingly important for actors with close geographical location links (Kylänen \& Mariani, 2014; Mariani et al., 2014). 
Figure 1: Conceptualisation of diaspora tourism

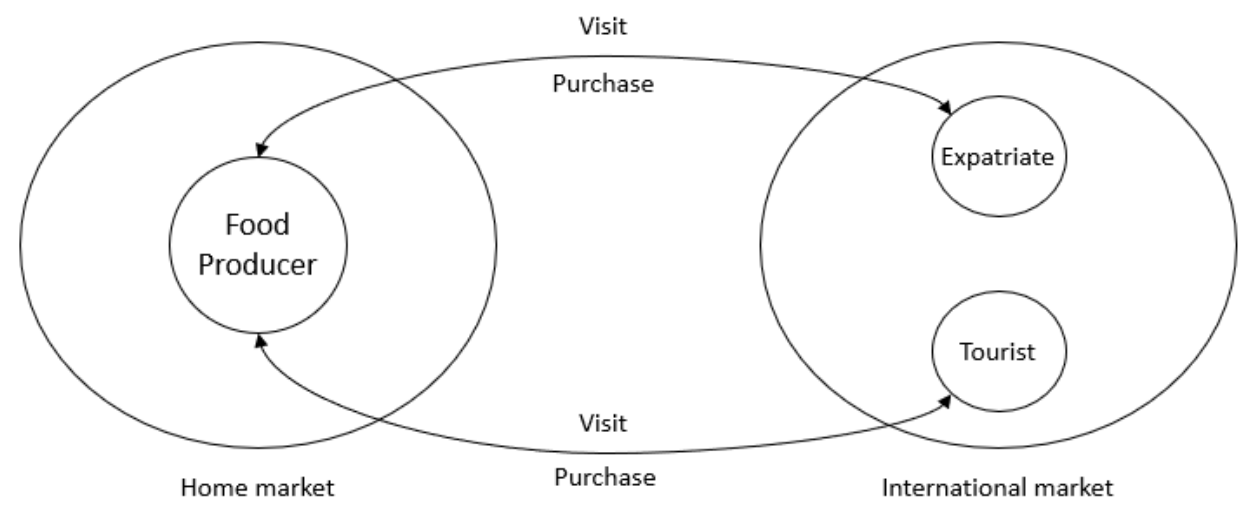

\section{Methodology}

As the objectives of this research pertain to the investigation of the influence of diaspora marketing and the diaspora effect in food tourism, the research design is exploratory. As an under-researched area, this research aims to shed more light on the reverse diaspora effect, therefore a sequential mixed methods design is adopted with the aim of gathering and interpreting a wealth of data to explore the various issues that relate to this concept. The use of mixed methods in this context aligns with discussions of Mariani and Baggio (2020) on the advantages of mixed methods in tourism research as a means of gleaning a deeper and more realistic understanding of the phenomenon, as well applying this methodology on research involving network theory. Limited research on this topic is largely conceptual (Kumar \& Steenkamp, 2013; Wilson et al., 2009), with empirical research by Elo et al. (2020) adopting an exploratory qualitative case study methodology, therefore the use of mixed methods here allows for this topic to be explored in more depth, expanding on existing knowledge of this topic. Adhering to the researcher's pragmatist standpoint, based on the 'what works' principle (Creswell and Plano Clark, 2017) the use of sequential independent phases within the mixed methods design of this research allows for initial variables to be tested through quantitative research, followed by a qualitative phase, allowing for respondents to provide context on the initial issues identified, as well as elaborating on their experiences. Specifically, the research is designed around a self-complete online questionnaire in the initial quantitative phase, based on descriptive company data, and variables focussed on network theory and product identity, with the aim of developing an understanding of how these variables impact on the ability to sell food products to international buyers, as well as exploring where these sales occur. Questions focussed on networking activities of the business, specifically in engaging with diaspora networks, as well as exploring diaspora links through international sales. Descriptive data was collected to build a profile of the business, allowing for suitable interview respondents to be identified. Secondly, follow-up semistructured interviews in the qualitative phase allow for elaboration on these issues and a deeper understanding of the experiences of food businesses in engaging in possible food tourism activities. Research participants were directors of food and drink producing SMEs located in Wales and Brittany. SMEs were identified under the European Commission (2018) definition of possessing less than 250 employees, and having a turnover of less than $50 \mathrm{~m} €$. 
Wales and Brittany were chosen as the research settings to allow for comparisons to be drawn from two locations that possess similar cultural and geographical characteristics, where food and drink represents a prominent part of the local economy. However, differences exist in the value of the food and drink industry, with a turnover of approximately $20 \mathrm{bn} €$ ( $£ 17.63 \mathrm{bn}$ ) in Brittany (Invest in Bretagne, 2017) compared to f6.1bn in Wales (Food and Drink Wales, 2018), and visitor numbers, with Brittany having 12.8 million tourists (16\% international tourists) in 2018 (Tourisme Bretagne, 2018), compared to 10.9 million tourists $(8.6 \%$ international tourists) in Wales (Statistics for Wales, 2019).

Respondents were selected from databases of food and drink SMEs for each location, established by the researcher through extensive evaluation of official documents and government websites. This resulted in a database of 451 food and drink producing SMEs in Wales, with 359 equivalent firms in Brittany, leading to a total population of 810 SMEs. Through probability sampling, with the aim of obtaining the highest number of responses, all companies in the databases were invited to participate in the questionnaire, leading to 169 usable responses (response rate of 20.86\%), of which 107 were from Welsh SMEs and 62 from Brittany. Questionnaire respondents were invited to participate in the follow-up interview phase based on maximum variation sampling, to ensure that interview respondents were representative of the various characteristics of companies, according to company size, location, and activity. This led to a total of 37 interviews, of which 20 were in Wales and 17 in Brittany. Interview questions focussed on the companies' experiences in engaging in diaspora networks, food tourism activities and international sales. Questionnaire data was analysed initially through descriptive statistics of company activities, as well as a logistic regression analysing variables relating to network theory against their ability to sell their products internationally. Interviews were transcribed verbatim and analysed using discourse analysis, identifying themes within the data. Both research phases were weighted equally, and conducted and analysed independently, with data triangulated for interpretation.

\section{Findings}

The findings of the research, presented in this section, are based on 169 responses to the questionnaire in the first phase, with 37 follow-up interviews in the second phase.

\subsection{Questionnaire Findings}

Responses from the questionnaire show the majority of responses were from Welsh SMEs, with 107 responses, compared to 62 in Brittany. Differences in company profiles are observed between the two locations, with $32.7 \%$ of responding companies engaged in internationalisation in Wales, compared to $61.3 \%$ in Brittany. Responses show a relatively balanced distribution across the different company size categories of microenterprises (1-9 employees), small enterprises (10-49 employees), and medium-sized enterprises (50-249 employees), highlighting that companies of all sizes had capabilities of internationalising. However, $84.4 \%$ of non-exporting enterprises were microenterprises.

The location of international sales of respondents shows that Europe is a significant market for both Welsh and Breton companies. Sales are observed to all regions, however, higher levels of sales are observed for Welsh SMEs in the Middle East and Oceania, while Breton 
SMEs see higher levels in Africa, Asia, North America and South America (Figure 2). This could partly be explained by colonisation, as Wales shows higher sales percentages in areas known for former British colonies, such as the Middle East and Oceania, whereas Breton companies see higher percentages in Africa. These align with diaspora connections for both Wales and Brittany. For North America, South America and Asia, this could be explained by Brittany having a more positive reputation for food, due to France's overall reputation for food.

Figure 2: Comparing the Location of International Sales

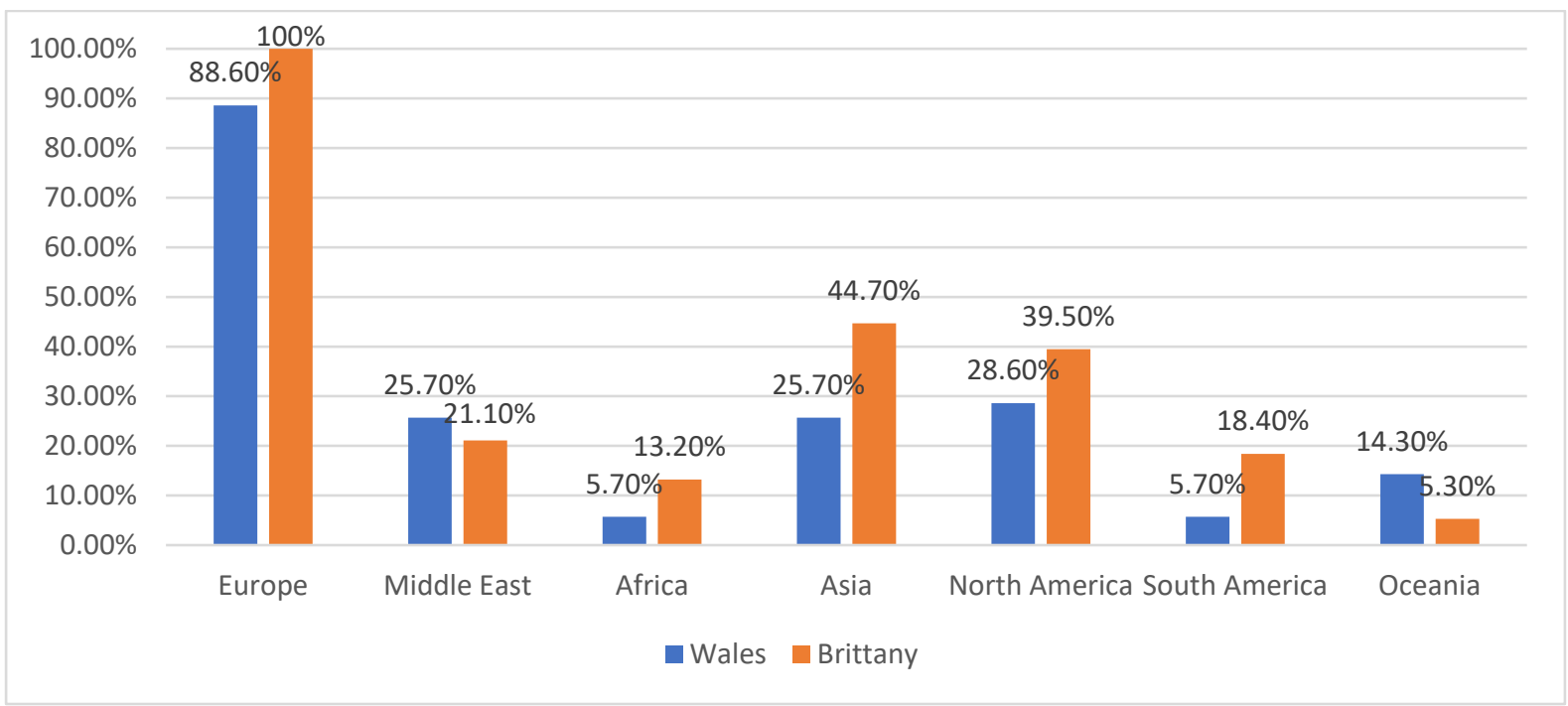

Observations of findings of variables relating to networks point to expatriate contacts as being the variable with the highest mean value, based on a Likert scale of 1-5 (Table 1). The expatriate contacts variable obtained the highest mean of 3.44 , followed by business cooperation (3.22) and finally $R \& D$ cooperation (3.02). The findings imply that network contacts could be useful in facilitating international sales for the food producers who responded to the questionnaire, especially expatriate contacts located in international markets, who could potentially provide opportunities for sales in those markets. Further analysis was conducted through a logistic regression relating these variables to internationalisation. Findings of the regression identified $R \& D$ cooperation as the only statistically significant network variable $(B=0.737$; Sig. $=0.003)$, with a positive relationship showing that the greater the access to $R \& D$ cooperation, the more likely the company is to internationalise. No statistical significance was observed for the expatriate contacts and business cooperation variables. Relating to product identity, the only statistically significant variable was for products with protected food names (PDO/PGI/TSG), indicating a positive relationship towards international sales.

Table 1: Combined Means for Network

\begin{tabular}{|l|r|r|r|r|r|}
\hline Item & Min. & Max. & Mean & $\begin{array}{l}\text { Standard } \\
\text { Deviation }\end{array}$ & Rank \\
\hline Expatriate contacts & 1.00 & 5.00 & 3.44 & 1.07 & 1 \\
\hline Business cooperation & 1.00 & 5.00 & 3.22 & 1.04 & 2 \\
\hline R\&D cooperation & 1.00 & 5.00 & 3.02 & 0.98 & 3 \\
\hline
\end{tabular}

Based on a 5-point Likert scale where 1=very insignificant and 5=very significant 
Questions relating to barriers to international sales pointed to limited foreign market information and unfamiliarity with legal practices or paperwork in foreign markets as being the variables with the highest mean value (both 3.51), while facilitating networking with partners (3.72) was a notable variable relating to supporting SMEs. However, none of these variables were statistically significant in the logistic regression. These findings imply that accessing international markets can be challenging for SMEs, with support needed to facilitate sales abroad, however, there is no barrier to selling products in international markets.

\subsection{Interview Findings}

Findings from the interviews are based on discussions with respondents about their business activities, opportunities to engage in food tourism, networks and international sales. A total of 37 interviews were conducted, of which 20 were with Welsh food producing SMEs and 17 with Breton SMEs. Table 2 provides a profile of interview respondents, distinguishing between companies that internationalise $(E)$ and those that do not $(N)$, as well as the company region, age and size.

Table 2: Profile of Respondents

\begin{tabular}{|c|c|c|c|c|c|c|c|}
\hline $\begin{array}{l}\text { Respon } \\
\text { dent }\end{array}$ & Region & $\begin{array}{l}\text { Company } \\
\text { Age } \\
\text { (years) }\end{array}$ & $\begin{array}{l}\text { Size } \\
\text { (employees) }\end{array}$ & $\begin{array}{l}\text { Respon } \\
\text { dent }\end{array}$ & Region & $\begin{array}{l}\text { Company } \\
\text { Age } \\
\text { (years) }\end{array}$ & $\begin{array}{l}\text { Size } \\
\text { (employees) }\end{array}$ \\
\hline N1 & Wales & $11-20$ & $10-49$ & E1 & Wales & $0-2$ & $1-9$ \\
\hline N2 & Wales & $11-20$ & $1-9$ & E2 & Wales & $11-20$ & $10-49$ \\
\hline N3 & Wales & $3-5$ & $1-9$ & E3 & Wales & $3-5$ & $1-9$ \\
\hline N4 & Wales & $11-20$ & $1-9$ & E4 & Wales & $21+$ & $10-49$ \\
\hline N5 & Wales & $11-20$ & $10-49$ & E5 & Wales & $11-20$ & $10-49$ \\
\hline N6 & Wales & $11-20$ & $10-49$ & E6 & Wales & $21+$ & $10-49$ \\
\hline N7 & Wales & $3-5$ & $1-9$ & E7 & Wales & $11-20$ & $1-9$ \\
\hline N8 & Wales & $3-5$ & $1-9$ & E8 & Brittany & $21+$ & $50-249$ \\
\hline N9 & Wales & $3-5$ & $1-9$ & E9 & Brittany & $21+$ & $1-9$ \\
\hline N10 & Wales & $3-5$ & $1-9$ & E10 & Brittany & $3-5$ & $1-9$ \\
\hline N11 & Wales & $21+$ & $1-9$ & E11 & Brittany & $21+$ & $1-9$ \\
\hline N12 & Wales & $3-5$ & $1-9$ & E12 & Brittany & $21+$ & $10-49$ \\
\hline N13 & Wales & $6-10$ & $1-9$ & E13 & Brittany & $0-2$ & $1-9$ \\
\hline N14 & Brittany & $0-2$ & $1-9$ & E14 & Brittany & $11-20$ & $1-9$ \\
\hline N15 & Brittany & $6-10$ & $1-9$ & E15 & Brittany & $21+$ & $50-249$ \\
\hline N16 & Brittany & $21+$ & $10-49$ & & & & \\
\hline N17 & Brittany & $6-10$ & $1-9$ & & & & \\
\hline N18 & Brittany & $21+$ & $1-9$ & & & & \\
\hline N19 & Brittany & $21+$ & $1-9$ & & & & \\
\hline N2O & Brittany & $21+$ & $10-49$ & & & & \\
\hline N21 & Brittany & $11-20$ & $1-9$ & & & & \\
\hline N22 & Brittany & $11-20$ & $1-9$ & & & & \\
\hline
\end{tabular}

Maximum variation sampling was used to ensure that interview respondents were representative of the companies that participated in the questionnaire, with representation covering each category of business in terms of size, location and activity. Among the interview 
respondents, 7 of the 20 respondents from Wales were involved in selling their products internationally, compared to 8 of the 17 respondents in Brittany. Interview data was transcribed verbatim and coded through first and second cycle coding (Miles et al., 2014), leading to three main themes of networks, diaspora networks, and product identity. Each of these themes are discussed hereafter.

\subsection{Networks}

Respondents pointed to the importance of networks in helping SMEs overcome limited resources, and the interviews implied that network connections were seen on different levels, at the company level, as well as local, national and international levels. Companies E4, E6, E8, and $\mathrm{E} 15$ possessed international employees within the company that could provide access to international markets through contacts. On a local level, companies alluded to engagement with other food companies as a means for sharing resources or providing support. Trust was a notable issue in network connections. This was true for respondent E1, who stated: "I've just got a network of people that I can trust, and I ask them when I need to". The same is true on a national level, through the development of cluster groups.

"There are several different cluster groups around at the moment...it's just that the more you see these people, the more you develop those relationships and that trust...But just sharing that knowledge and that networking across Wales is massively important." (Respondent E3)

In Brittany, the Produit en Bretagne association acted as an effective network group for its members, bringing producers together with the ability to share resources and experiences in international markets. On an international level, the use of distributors is significant in facilitating internationalisation for small food producers who lack knowledge of foreign markets and logistics capabilities.

\subsection{Diaspora Networks}

While a number of respondents acknowledged networks as important in supporting their business activities, particularly in establishing international growth opportunities, fewer respondents were engaged with diaspora networks. This was especially true among Welsh respondents, with only 3 respondents acknowledging diaspora connections, compared to 10 respondents in Brittany. Advantages of diaspora networks were seen in expatriate contacts located in international markets who were able to facilitate international connections. For respondent E5, opportunities to sell products in China were facilitated through expatriate links.

"We had a contact who does a lot of exporting in China, in fact he runs a food import export company in China, and he only really clocked on that it was Welsh because his father was from Aberystwyth." (Respondent E5)

Diaspora connections were more common among respondents in Brittany, as international sales were established through links with Breton chefs located in London or Barcelona, as well as Breton creperies located in London or Berlin. These relationships were also based on trust, and common values of supporting Breton produce. 
"Breton people travel a lot, I mean there are many Breton chefs in other places in France, so the product is important to them too and they would need it for their cooking...Yes there are a few French chefs in London, for example and they are naturally attracted to the product." (Respondent E14).

Although few respondents engaged directly in tourism activities, reverse diaspora effects were experienced by several respondents who possessed visitor centres at their production sites. This was more evident in Brittany, where 5 respondents possessed a visitor centre, compared to 3 in Wales. Visitor centres provided businesses with opportunities to engage with tourists in the local area, providing more information about the products, many of which have strong cultural identities, such as cider in Brittany, or fudge in Wales.

"We welcome a lot of visitors to our distillery and visitor centre during the summers, when we run distillery tours. Many people from these countries visit Brittany every year, so it's important for us that people can visit the distillery to sample and even buy our products. We do find that some people who have visited us here then place orders online to buy more products." (Respondent E12)

\subsection{Product identity}

A number of respondents possessed products with strong cultural identities to their respective regions, such as cider in Brittany, or fudge in Wales. The product identities were useful for the companies in marketing their products, both domestically and in international markets, where consumers were more aware of the products and their identity. This was more common in Europe, as well as in countries with colonial connections to Wales and Brittany. Awareness of product identity was an aspect of facilitating connection with diaspora networks, as expatriates were aware of the products and their cultural value. The use of a 'Made in' logo was observed in Brittany, where companies who are members of the Produit en Bretagne association and brand (E9, E12, E13, E15, N16, N20) spoke highly of its benefits, bringing not only product awareness, but providing support to companies through its network of members. Whereas no association or brand currently exists in Wales, respondents E2, E3, E5 and E7 spoke positively about the benefits a 'Made in Wales' brand could bring, if done right. This was echoed by respondent E9.

"It's true that Breton people buy Produit en Bretagne products, even across the rest of France, the logo is widely recognised, especially as we live at a time when people want to buy the products from their own regions. For the logo, that is something that people certify as being made in Brittany. That is why the logo is interesting for me, so at some point a Made in Wales logo could be important, it could be something that could help sell well in England, not just in Wales." (Respondent E9)

However, some questioned the strength in identity of certain food products, particularly in Wales, where some producers acknowledged that the reputation for food in Wales was not yet widespread: "The Food and Drink industry in Wales is in its youth, and its reputation is growing but it is not mature enough to be recognised as a destination for food outside the UK." (Respondent N13). 


\section{Discussion}

Research from both phases underline the positioning of diaspora marketing within a broader scope of network aspects, as well as tourism. Findings support the conceptualisation for diaspora tourism seen in Figure 1, as the two avenues for diaspora tourism were observed in the study, namely engagement with expatriate networks in international markets, and the reverse diaspora effect of visitors experiencing the product in-place before seeking to purchase from their home market. Both avenues are dependent on the ability of the company to sell their products to international purchases. Findings show that food producers in both research settings had opportunities to engage in food tourism activities, and sell their products in international markets. Despite being SMEs, a number of respondents sold their food products in international markets across all parts of the world. Challenges of limited resources and market knowledge were overcome through developing network connections, including diaspora networks, and enhancing the awareness of the products through emphasising the cultural identity. These findings align with network theory in that internationalisation is not a solo effort for SMEs, who often rely on the support of various actors in facilitating international sales (Mtigwe, 2006). Findings in Figure 2 suggest that international sales were more prominent in places with colonial links to Wales or Brittany, implying that there may be scope for using colonial ties, or diaspora connections to facilitate opportunities to sell products in these markets. Indeed, an evaluation of mean values presented in Table 1 pointed to expatriate connections as the highest ranked network variable. This echoes the situation of fish exporters from the Azores, who engaged with expatriates in Canada and the USA (Camara \& Simeos, 2008). A regression analysis showed no statistical significance for the expatriate connections variable, suggesting that they do not influence internationalisation.

Interview findings placed value in the role of network connections supporting SMEs to sell their products internationally, emphasising the need for trust with network partners. Greater trust was observed with expatriate contacts, who shared common values, leading to close relationships in supporting international sales. Network theory states that relationships between a company and intermediaries are an important source of competitive advantage for international sales (Kuhlmeier \& Knight, 2010; Wilson, 2006). It could therefore be considered that the relationships with diaspora network partners, based on closer relations and increased levels of trust, could provide greater value to food producers in supporting internationalisation. Indeed, literature on entrepreneurial ecosystems (cf. Isenberg, 2011; Ratten \& Rashid, 2020; Stam \& Spigel, 2016; van Schijndel, 2019) could be expanded to include considerations of diaspora network partners, due to the strength of these relationships based on trust.

Network theory could also support findings of diaspora marketing observed in this research, particularly in the relations that food producers had with chefs and restaurants located abroad. In a globalised society, with demand for international foods, opportunities exist for food producers in the native country to supply culturally-specific restaurants abroad, leading to increased sales and awareness of the company in international markets. This was primarily observed among Breton respondents, with some companies supplying chefs of Breton origin, 
or Breton-themed creperies in major European cities. This could be explained by the positive reputation that exists for food in Brittany, and in France more generally, leading to a demand for Breton food. This could also be attributed to the cultural identity of food, which was a theme within interview responses. Respondents from both Wales and Brittany possessed food products with a notable cultural identity to place, although this was more prominent in Brittany, and further supported through the Produit en Bretagne brand, indicating provenance of the products. Considering Resource-based View theory (Barney, 1991; Teece, 2007), the unique characteristics of these foods associated with their places of origin, particularly the terroir (Charters et al., 2017), represent a source of competitive advantage, providing distinctions from other similar products (Testa, 2011), underlining a sense of place (Hede \& Watne, 2013). These characteristics amplify the authenticity of the food product, enhancing its value in the local tourism offering (Ellis et al., 2018; Kim et al., 2010).

Food tourism opportunities were observed through food producers possessing visitor centres at their site of production, as a means of welcoming visitors, and engaging in wider tourism activities, such as visits, tours, or tastings (Everett, 2016). A number of interview participants possessed visitor centres (E2, E9, E10, E11, E12, E15, N8, N9, N10, N12, N16, N17, N21), which provides supplementary income to food producers (Getz \& Brown, 2006). Findings showed that some respondents, particularly in Brittany (E9, E10, E11, E12, E15), benefitted from reverse diaspora effects through welcoming visitors to their visitor centres, where they could sample and buy food products, before also seeking to purchase products once they had returned home (Kumar \& Steenkamp, 2013). This presents an opportunity for the food producers to increase sales in international markets in a relatively low risk manner, without the need to engage with intermediaries. Selling products in international markets in this way serves to spread the risk of the business across multiple buyers, placing less reliance on the domestic market (Spowart \& Wickramasekera, 2012).

Considering the opportunities through food tourism observed from respondents, local food producers could take a more proactive approach towards food tourism. This could be seen in developing visitor centres on their production site as a means of selling products directly to customers, as well as providing visitors with an enhanced tourism offering, through opportunities to learn more about the products and production process, as well as taste the products. As experienced by several respondents to this research, this could lead to reverse diaspora effects (Kumar \& Steenkamp, 2013). Additional tourism opportunities exist through promoting the cultural value of the products, many of which in this study were cultural products specific to the locality. The unique characteristics of place serve to distinguish the foods from other similar products, developing inimitable qualities (Barney, 1991). Food is recognised as a significant motivator for food tourism (Ellis et al., 2018; Kim et al., 2010; Robinson et al., 2018), and places are increasingly aware of the value of local foods to tourism strategies (Du Rand \& Heath, 2006; Okumus et al., 2007). Food producers could take a more proactive approach to developing local tourism strategies, such as local tourism trails, through cooperation with other local food producers.

Tourism strategies of place could also align with diaspora strategies, to promote local produce and engage with expatriates, or those with an affinity to the country or region. Examples of 
this have been seen in Ireland with 'homecoming' strategies aimed at attracting expatriates back to visit Ireland (Hughes \& Allen, 2010). As a small country of 4.4 million people, engagement with its diaspora has been valuable to Ireland, opening up to diaspora network of around 70 million (Aikins et al., 2009). As regions of similar sizes and with similar cultural values, both Wales and Brittany have the potential to tap into their global diaspora networks. The value of the Produit en Bretagne association has already been documented, but initiatives such as Breizh Amerika, the Breton diaspora association in America (Breizh Amerika, 2021), or Global Welsh (Global Welsh, 2021), the Welsh diaspora network, play an important role in supporting companies from their home region in seeking foreign market connections that can lead to internationalisation, as well as opportunities to promote tourism.

\section{Conclusion}

\subsection{Research and theoretical contributions}

This research has shed light on an under-researched area of food tourism, notably the role of diaspora networks in facilitating food tourism opportunities. This was observed, predominantly in Brittany, through network connections with expatriate contacts in international markets, such as Breton chefs or creperies located internationally seeking supplies of Breton produce. Additionally, food producers could enhance food tourism opportunities by selling products directly to tourists at their visitor centres, leading to the reverse diaspora effect, with customers seeking repeat purchases after returning home. As an issue that has seen limited research, the exploratory nature of this research highlights that several food producers have experienced benefits of diaspora marketing on their business by increasing sales in international markets, either through a strategy of targeting known expatriate contacts abroad, or through indirect advantages of selling products to tourists through a visitor centre. This initial research has identified themes of networks connections, diaspora networks, and product identity, which could form the basis of future research to add more breadth to knowledge on this subject. The paper makes three contributions to research on food tourism and diasporas, initially by conceptualising diaspora tourism through the intersection of food tourism, diaspora marketing and entrepreneurship, under the lens of network theory. This is explored through a mixed methods research design, and a focus on food businesses as the unit of analysis.

\subsection{Practical implications}

Implications for practice from this research point to opportunities for food producers to engage in food tourism activities, where resources allow for this, most notably through expatriate contacts that they possess in international markets. These relationships are often based on trust, due to longstanding connections, or values stemming from common origins. Furthermore, food producers could be proactive in developing opportunities to facilitate food tourism by opening a visitor centre at the site of production. This serves to enable the producer to engage with domestic or international tourists in the local area, allowing for visitors to develop more informative awareness of the products. Additionally, benefits are seen in supplementing the business activity of the food producer, leading to the potential for international sales. It is considered that supplementary activities by food producers could 
help enhance a local identity for food. With that in mind, local strategies could be established to engage various food producers in local food trails, which could bring mutual benefits to participating producers, as a means of promoting the local identity for food, as well as promoting participating businesses. Furthermore, regional or national strategies for engaging with diaspora networks could be established, with the aim of empowering local food producers to adopt tourism activities, and promote the cultural values of local foods.

\subsection{Limitations and research agenda}

As exploratory research, limitations are observed in the scope of the methodology, with few statistically significant variables evident in the quantitative findings, placing greater value on the qualitative phase of the study in providing contextual data that underlined respondents' experiences relating to diaspora marketing. Future research should consider new research settings to account for cultural factors that may influence the propensity for engagement with diaspora contacts, as well as opportunities for tourism in the observed location.

\section{References}

Aikins, K., Sands, A., \& White, N. (2009). A Comparative Review of International Diaspora Strategies: The Global Irish Making A Difference Together. The Ireland Funds.

Aikins, K., \& White, N. (2011). Global Diaspora Strategies Toolkit: Harnessing the power of global diasporas. Diaspora Matters.

Barney, J. B. (1991). Firm Resources and Sustained Competitive Advantage. Journal of Management, 17(1), 99-120.

Bourdieu, P., \& Wacquant, L. J. D. (1992). An invitation to reflexive sociology. University of Chicago press.

Bowen, R., \& Bennett, S. (2020). Selling places: a community-based model for promoting local food. The case of Rhondda Cynon Taf. Journal of Place Management and Development, 13(2), 215-228.

Breizh Amerika. (2021). Breizh Amerika. https://www.breizh-amerika.com/

Broadway, M. J. (2017). 'Putting Place on a Plate' along the West Cork Food Trail. Tourism Geographies, 19(3), 467-482.

Bujdosó, Z., \& Szûcs, C. (2012). Beer tourism-from theory to practice. Academica Turistica, 5(1), 103-111.

Cabras, I., Lorusso, M., \& Waehning, N. (2020). Measuring the economic contribution of beer festivals on local economies: The case of York, United Kingdom. International Journal of Tourism Research, 22(6), 739-750.

Camara, F. J. L., \& Simeos, V. C. (2008). Social Networks as Drivers of Internationalisation Patterns: A Case Study on Fish Exports. Mimeo.

Charters, S., Spielmann, N., \& Babin, B. J. (2017). The nature and value of terroir products. European Journal of Marketing, 51(4), 748-771. 
Creswell, J. W., \& Plano Clark, V. L. (2017). Designing and conducting mixed methods research. Sage publications, Thousand Oaks, California.

Czakon W. (2014) Network Structure and Performance in the Tourism Industry. In: Mariani M.M., Baggio R., Buhalis D., Longhi C. (eds) Tourism Management, Marketing, and Development. Palgrave Macmillan, New York.

Du Rand, G. E., \& Heath, E. (2006). Towards a framework for food tourism as an element of destination marketing. Current Issues in Tourism, 9(3), 206-234.

Ellis, A., Park, E., Kim, S., \& Yeoman, I. (2018). What is food tourism? Tourism Management, $68,250-263$.

Elo, M., Minto-Coy, I., Silva, S. C. E., \& Zhang, X. (2020). Diaspora networks in international marketing: how do ethnic products diffuse to foreign markets? European Journal of International Management, 14(4), 693-729.

European Commission. (2018). What is an SME. https://ec.europa.eu/growth/smes/business-friendly-environment/sme-definition_en

Everett, S. (2016). Food and Drink Tourism: Principles and Practice. SAGE Publications, London.

Everett, S., \& Aitchison, C. (2008). The Role of Food Tourism in Sustaining Regional Identity: A Case Study of Cornwall, South West England. Journal of Sustainable Tourism, 16(2), 150-167.

Food and Drink Wales. (2018). Key Facts. https://businesswales.gov.wales/foodanddrink/about-us/key-facts

Gamlen, A. (2005). The brain drain is dead: Iong live the New Zealand diaspora. In Centre for Migration, Policy and Society. University of Oxford.

Getz, D. (2008). Event tourism: Definition, evolution, and research. Tourism Management, 29(3), 403-428.

Getz, D., \& Brown, G. (2006). Critical success factors for wine tourism regions: a demand analysis. Tourism Management, 27(1), 146-158.

Global Welsh. (2021). Global Welsh. https://globalwelsh.com/

Gómez, M., \& Molina, A. (2012). Wine Tourism in Spain: Denomination of Origin Effects on Brand Equity. International Journal of Tourism Research, 14(4), 353-368.

Hall, C. M., \& Sharples, L. (2004). The consumption of experiences or the experience of consumption? An introduction to the tourism of taste. In Food tourism around the world (pp. 13-36). Routledge.

Hede, A.-M., \& Watne, T. (2013). Leveraging the human side of the brand using a sense of place: Case studies of craft breweries. Journal of Marketing Management, 29(1-2), 207-224.

Holak, S. L. (2014). From Brighton beach to blogs: Exploring food-related nostalgia in the Russian diaspora. Consumption Markets \& Culture, 17(2), 185-207. 
Holt, D. B. (2004). How Brands Become Icons: The Principles of Cultural Branding. Harvard Business Press.

Huang, W.-J., Hung, K., \& Chen, C.-C. (2018). Attachment to the home country or hometown? Examining diaspora tourism across migrant generations. Tourism Management, 68(1), 52-65.

Huang, W.-J., Ramshaw, G., \& Norman, W. C. (2016). Homecoming or tourism? Diaspora tourism experience of second-generation immigrants. Tourism Geographies, 18(1), 5979.

Hughes, H., \& Allen, D. (2010). Holidays of the Irish diaspora: The pull of the 'homeland'? Current Issues in Tourism, 13(1), 1-19.

Invest in Bretagne. (2017). Food Industry and Agriculture.

Isenberg, D. J. (2011). The entrepreneurship ecosystem strategy as a new paradigm for economy policy: principles for cultivating entrepreneurship. Babson Entrepreneurship Ecosystem Project, Babson College, Babson Park: MA.

Johanson, J., \& Mattson, L. G. (1988). Internationalization in industrial systems: A network approach. In N. Hood \& J. E. Vahlne (eds.), Strategies in global competition (pp. 287314). Croom Helm.

Kapur, D. (2001). Diasporas and technology transfer. Journal of Human Development, 2, 265-286.

Kim, S., \& Iwashita, C. (2016). Cooking identity and food tourism: the case of Japanese udon noodles. Tourism Recreation Research, 41(1), 89-100.

Kim, Y. G., Suh, B. W., \& Eves, A. (2010). The relationships between food-related personality traits, satisfaction, and loyalty among visitors attending food events and festivals. International Journal of Hospitality Management, 29(2), 216-226.

Knollenberg, W., Duffy, L. N., Kline, C., \& Kim, G. (2020). Creating Competitive Advantage for Food Tourism Destinations Through Food and Beverage Experiences. Tourism Planning \& Development, 1-19.

Kuhlmeier, D. B., \& Knight, G. A. (2010). The critical role of relationship quality in small- and medium-sized enterprise internationalization. Journal of Global Marketing, 23(1), 1632.

Kumar, N., \& Steenkamp, J.-B. E. M. (2013). Diaspora Marketing. Harvard Business Review, 91, 127-150.

Kunasegaran, M., Rasoolimanesh, S. M., \& Kadar Khan, S. (2019). Experiences of international tourists with healthy signature foods: a case study in Malacca. British Food Journal, 122(6), 1869-1882.

Kylänen M., Mariani M.M. (2014) Cooperative and Coopetitive Practices: Cases from the Tourism Industry. In: Mariani M.M., Baggio R., Buhalis D., Longhi C. (eds) Tourism Management, Marketing, and Development. Palgrave Macmillan, New York.

Laing, J., \& Frost, W. (2013). Food, wine... heritage, identity? Two case studies of Italian 
diaspora festivals in regional Victoria. Tourism Analysis, 18(3), 323-334.

Larner, W. (2007). Expatriate experts and globalising governmentalities: the New Zealand diaspora strategy. Transactions of the Institute of British Geographers, 32, 331-345.

Li, T. E., \& Chan, E. T. H. (2017). Diaspora tourism and well-being: A eudaimonic view. Annals of Tourism Research, 63, 205-206.

Mariani M.M., Baggio R., Buhalis D., Longhi C. (2014) Conclusion. In: Mariani M.M., Baggio R., Buhalis D., Longhi C. (eds) Tourism Management, Marketing, and Development. Palgrave Macmillan, New York.

Mariani, M., \& Baggio, R. (2020). The relevance of mixed methods for network analysis in tourism and hospitality research. International Journal of Contemporary Hospitality Management, 32(4), 1643-1673

Meneguel, C. R. de A., Mundet, L., \& Aulet, S. (2019). The role of a high-quality restaurant in stimulating the creation and development of gastronomy tourism. International Journal of Hospitality Management, 83, 220-228.

Miles, M. B., Huberman, A. M., \& Saldana, J. (2014). Qualitative Data Analysis: A Methods Sourcebook. SAGE Publications, Thousand Oaks, California.

Morgan, N., \& Pritchard, A. (2005). On souvenirs and metonymy: Narratives of memory, metaphor and materiality. Tourist Studies, 5(1), 29-53.

Moscardo, G., Minihan, C., \& O'Leary, J. (2015). Dimensions of the food tourism experience: Building future scenarios. The Future of Food Tourism: Foodies, Experiences, Exclusivity, Visions and Political Capital, 208-224.

Mtigwe, B. (2006). Theoretical milestones in international business: The journey to international entrepreneurship theory. Journal of International Entrepreneurship, 4, 525.

OECD. (2009). Top Barriers and Drivers to SME Internationalisation. Report by the OECD Working Party on SMEs and Entrepreneurship, OECD.

Okumus, B., Okumus, F., \& McKercher, B. (2007). Incorporating local and international cuisines in the marketing of tourism destinations: The cases of Hong Kong and Turkey. Tourism Management, 28(1), 253-261.

Ratten, V., \& Rashid, S. (2020). Entrepreneurial Ecosystems: Future Research Ideas. In Ratten, V. (ed.) Entrepreneurship as Empowerment: Knowledge Spillovers and Entrepreneurial Ecosystems. Emerald Publishing Limited, Bingley, 151-163.

Robinson, R. N. S., Getz, D., \& Dolnicar, S. (2018). Food tourism subsegments: A data-driven analysis. International Journal of Tourism Research, 20(3), 367-377.

Spowart, M., \& Wickramasekera, R. (2012). Explaining Internationalisation of Small to Medium Sized Enterprises within the Queensland Food and Beverage Industry. International Journal of Business and Management, 7(6), 68-80.

Stam, F. C., \& Spigel, B. (2016). Entrepreneurial ecosystems. USE Discussion Paper Series, 
16(13).

Statistics for Wales. (2019). Wales Tourism Performance Report : January to June 2018.

Swarbrooke, J., \& Page, S. J. (2012). Development and management of visitor attractions. Routledge, Oxford.

Teece, D. J. (2007). Explicating dynamic capabilities: the nature and microfoundations of (sustainable) enterprise performance. Strategic Management Journal, 28(13), 13191350.

Testa, S. (2011). Internationalization patterns among speciality food companies: some Italian case study evidence. British Food Journal, 113(11), 1406-1426.

Tourisme Bretagne. (2018). Tourism Chiffres Clés.

Tregear, A., Török, Á., \& Gorton, M. (2015). Geographical indications and upgrading of smallscale producers in global agro-food chains: A case study of the Makó Onion Protected Designation of Origin. Environment and Planning A, 48(2), 433-451.

van Schijndel, L. (2019). TCKF-Connect: a Cross-Disciplinary conceptual framework to investigate internationalization within the context of entrepreneurial ecosystems. Journal of Open Innovation: Technology, Market, and Complexity, 5(2), 28.

Weaver, D. B., Kwek, A., \& Wang, Y. (2017). Cultural connectedness and visitor segmentation in diaspora Chinese tourism. Tourism Management, 63, 302-314.

Williams, E. (2013). Food museums. In Albala, K. (ed.) Routledge International Handbook of Food Studies, 229-237, Routledge, London.

Wilson, J., Fisher, D., \& Moore, K. (2009). Reverse diaspora and the evolution of a cultural tradition: The case of the New Zealand 'Overseas Experience.' Mobilities, 4(1), 159175.

Wilson, K. (2006). Encouraging the Internationalisation of SMEs. OECD Papers, 6(12), 43-66. 